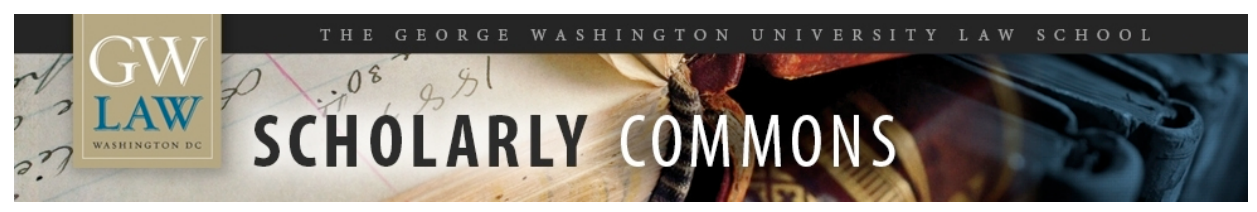

\title{
Comment Letter to the U.S. Treasury Department Concerning the Regulatory Structure for Financial Institutions
}

Arthur E. Wilmarth Jr.

George Washington University Law School, awilmarth@law.gwu.edu

Follow this and additional works at: https://scholarship.law.gwu.edu/faculty_publications

Part of the Law Commons

\section{Recommended Citation}

Wilmarth, Arthur E. Jr., "Comment Letter to the U.S. Treasury Department Concerning the Regulatory Structure for Financial Institutions" (2007). GW Law Faculty Publications \& Other Works. 1003.

https://scholarship.law.gwu.edu/faculty_publications/1003

This Response or Comment is brought to you for free and open access by the Faculty Scholarship at Scholarly Commons. It has been accepted for inclusion in GW Law Faculty Publications \& Other Works by an authorized administrator of Scholarly Commons. For more information, please contact spagel@law.gwu.edu. 


\section{George Washington University Law School 2000 H STREET, N.W. WASHINGTON, DC 20052 \\ TEL: (202) 994-6386; FAX: (202) 994-9446 \\ EMAIL:AWILMARTH@LAW.GWU.EDU}

November 21, 2007

United States Department of the Treasury

Washington, DC

Re: $\quad$ Request for comments on "Regulatory

Structure Associated with Financial

Institutions," Docket No. TREAS-DO-2007-

0018

Thank you for the opportunity to submit these comments in connection with the Treasury Department's consideration of proposals for changes in the current structure of regulation for financial institutions. My comments will focus on the regulation of depository institutions insured by the Federal Deposit Insurance Corporation (FDIC). At the end of each section of my comments, I will present one or more specific policy recommendations based on the discussion in that section.

The comments set forth below represent my personal opinions and do not represent the views of The George Washington University or any other organization.

\section{A. Eliminating the Thrift Charter}

For three reasons, the thrift charter should be abolished, and savings associations should be required to convert into either national banks or state-chartered banks (at the option of each converting institution). First, the powers and activities of thrift institutions and commercial banks have become increasingly similar over the past 25 years. Second, Congress combined the deposit insurance funds for thrifts and banks in 2005. Accordingly, there is no longer any compelling reason for maintaining separate thrift and banking industries.

Second, despite their increasing convergence with commercial banks, thrift institutions remain excessively dependent on housing finance. As shown by the present crisis involving subprime and nonprime mortgage lending, any financial institution charter that focuses significantly on home financing presents excessive risks to the federal safety net for financial institutions. The current crisis is a reminder of what the nation should have learned from the savings and loan debacle of the 1980s - the thrift industry's business focus is too narrow to develop a broad and reliable base for long-term profitability. The current crisis has already imposed severe losses on at least three of the largest thrift institutions - Countrywide, Washington Mutual and IndyMac. The losses reported by those institutions reveal that even the largest thrifts are vulnerable to severe downturns in the housing industry, an industry which has repeatedly experienced boom-and-bust cycles since the 1920 s. 
Accordingly, the thrift charter should be eliminated. Concurrently, the supervisory functions and staff of the Office of Thrift Supervision (OTS) should be transferred to the Office of the Comptroller of the Currency (OCC).

\section{Policy Recommendation No. 1: Abolish the thrift charter and merge the OTS with the OCC.}

\section{B. Preserving the Dual Banking System and Community Banks}

Congress has supported a dynamic and competitive dual banking system for more than a century. The dual banking system has conferred three major benefits on the U.S. financial services industry. First, the states have acted as "laboratories" in experimenting with new banking products, structures and supervisory approaches, and Congress has subsequently incorporated many of the states' successful innovations into federal legislation. Examples of state experiments adopted by Congress include: checking accounts, bank branches, bank holding companies, real estate loans, trust services, negotiable order of withdrawal accounts, deposit insurance, adjustable-rate mortgages, automated teller machines, interstate electronic funds transfer systems, bank sales of insurance products, regional interstate banking compacts, and supervisory agreements that ensure cooperative oversight of multistate banking organizations by state bank regulators, the Federal Reserve Board (FRB) and the FDIC. No other banking system in the world can match the dual banking system's record of continuous innovation. ${ }^{1}$

Second, by creating a choice between federal and state charters, the dual banking system allows banks to escape from arbitrary or inflexible regulation. It creates a dynamic rivalry between the national and state banking systems that encourages innovative and responsive regulation. In 1984, the Presidential Task Force on Regulation of Financial Services hailed the dual banking system as "one of the finest examples of cooperative federalism in the nation's history." The Task Force praised the dual banking system because (i) it "provided a safety valve against out-dated or inflexible regulatory controls being imposed by either federal or state authorities," and (ii) it enabled the states to act as "laboratories for change."2

Third, the state banking system has acted as an incubator for smaller, communityoriented banks. Over the past decade, more than three-quarters of newly-chartered ("de novo") banks have chosen to operate under state charters. State banking departments are more accessible to community banks and are more responsive to the views and needs of community

1 For a discussion of the historical background and advantages of the dual banking system, see Arthur E. Wilmarth, Jr., “The OCC's Preemption Rules Exceed the Agency's Authority and Present a Serious Threat to the Dual Banking System and Consumer Protection," 23 Annual Review of Banking and Financial Law 225 (2004) (available at http://ssrn.com/abstract= 577863) (hereinafter Wilmarth, "Dual Banking System"), at 253-65.

${ }^{2}$ Id. at 262 (quoting the Bush Task Group Report on Regulation of Financial Services: Blueprint for Reform (1984)). 
bankers. In contrast, the OCC is primary focused on promoting the interests of large national banks, which fund most of the OCC's budget. ${ }^{3}$ The OCC's bias in favor of larger banks is revealed by its schedule for assessments, which imposes much higher marginal rates on small national banks. For example, the OCC's marginal assessment rate for national banks with assets between $\$ 2$ million and $\$ 100$ million is (i) about twice as high as its marginal assessment rate for banks with assets between $\$ 100$ million and $\$ 1$ billion, (ii) more than three times as high as its marginal assessment rate for banks with assets between $\$ 6$ billion and $\$ 20$ billion, and (iii) more than six times as high as its marginal assessment rate for banks with assets of more than $\$ 40$ billion. It is hardly surprising that the great majority of community banks select state charters. Accordingly, preservation of the state charter option is essential to preserve a vibrant community banking sector.

The dual banking system in the United States is a decentralized, diverse system composed of more than 7,000 banks, including thousands of community banks, scores of midsized regional banks, and a smaller group of large, multistate banking organizations. Community banks play a crucial role in providing credit and other financial services to consumers and small and medium-sized enterprises (SMEs). ${ }^{4}$ In contrast to the United States, Canada and the United Kingdom each have fewer than 100 banks. The highly concentrated banking systems of both nations are dominated by a handful of big banks. As a result, very few community banks exist in Canada and the U.K. ${ }^{5}$ Due in large part to its thriving community

3 See Wilmarth, "Dual Banking System," supra note 1, at 264-65, 274-79, 296-97, 35356.

${ }^{4}$ Id. at 263-65; see also Arthur E. Wilmarth, Jr., "The Transformation of the U.S. Financial Services Industry, 1975-2000; Competition, Consolidation, and Increased Risks," 2002 University of Illinois Law Review 215 (2002) (available at http://ssrn.com/abstract=315345) (hereinafter Wilmarth, "Transformation”), at 254-72.

5 Canada has only about 70 banks, and the six largest banks dominate Canada's domestic banking markets. C.J. Shaw, "Big Bank Merger Review in Canada," 21 Journal of International Banking Law and Regulation 474, 475 (2006); Arthur E. Wilmarth, Jr., "Too Big to Fail, Too Few to Serve? The Potential Risks of Nationwide Banks," 77 Iowa Law Review 957 (1992) (hereinafter Wilmarth, "Too Big to Fail"), at 1052. Similarly, the U.K. has fewer than 100 banks, and the four largest banks dominate the U.K.'s domestic banking markets. Shelagh Heffernan, "UK bank services for small business: How competitive is the market?", 30 Journal of Banking and Finance 3087, 3089 (2006); Wilmarth, "Too Big to Fail," supra, at 1052; see also Glenn Hoggarth et al., "Alternative Routes to Banking Stability: A Comparison of UK and German Banking Systems," Financial Stability Review, Bank of England, Autumn 1998, at 55, 57 (reporting that the five largest U.K. banks accounted for $57 \%$ of the U.K.'s banking business in 1994). 
banking sector, the U.S. banking system has performed much better than the Canadian and U.K. systems in serving the needs of consumers and SMEs. ${ }^{6}$

By serving as the most important source of external credit for SMEs, community banks promote economic growth in the United States. SMEs account about half of the total private sector output, employ a majority of the private sector workforce, and account for more than a third of all private sector innovations. ${ }^{7}$ A 2004 study confirms the link between community banks, the success of SMEs and economic growth. Based on a review of banking systems in 49 countries, that study found that countries recorded faster growth rates in their gross domestic profit (GDP) if community banks accounted for a larger share of their banking system. The study concluded that the superior ability of community banks to provide relationship loans to SMEs was the most likely explanation for the observed correlation between community bank strength and faster GDP growth. ${ }^{8}$

However, the survival of the community banking sector and its success in serving the needs of retail customers and SMEs cannot be taken for granted. During 1990-2005, more than 5,400 bank mergers occurred in the United States, involving more than $\$ 5.0$ trillion in banking assets. During the same period, the percentage of banking assets held by the ten largest U.S. banks rose from $25 \%$ to $55 \% .{ }^{9}$ Extensive consolidation has occurred in many local, statewide

${ }^{6}$ Wilmarth, "Dual Banking System," supra note 1, at 263-65; Wilmarth, "Too Big to Fail," supra note 5, at 1038-40, 1052-55 (stating that "[t] he highly concentrated banking systems in both countries have long been characterized by oligopolistic behavior," $i d$. at 1052); see also Shaw, supra note 5, at 476 (noting that "[1]ike public utilities, the large [Canadian] banks are perceived to co-exist in a business environment which is (or very close to) oligopoly"). The largest Canadian banks have received widespread public criticism for their high profits, excessive fees and poor service to consumers and SMEs. See Gaétan Breton \& Louise Côté, "Profit and the legitimacy of the Canadian banking industry," 19 Accounting, Auditing \& Accountability Journal 512, 521-31 (2006). Two recent studies concluded that the "big four" U.K. banks displayed oligopolistic conduct in charging excessive prices for services to retail customers and SMEs. See Heffernan, supra note 5; Shelagh A. Heffernan, "How do UK financial institutions really price their banking products?", 26 Journal of Banking and Finance 1997 (2002). For additional reports criticizing major Canadian and U.K. banks, see sources cited in Wilmarth, "Dual Banking System," supra note 1, at 264 n.146.

7 Wilmarth, “Transformation," supra note 4, at 257-67.

8 Allen N. Berger et al., "Further Evidence on the Link between Finance and Growth: An International Analysis of Community Banking and Economic Performance," 25 Journal of Financial Services Research 169 (2004).

9 Kenneth D. Jones \& Robert Oshinsky, "The Effect of Industry Consolidation and Deposit Insurance Reform on the Resiliency of the U.S. Bank Insurance Fund," April 25, 2007 (available at http://ssrn.com/abstract $=997844$ ), at 1 . 
and regional markets. ${ }^{10}$ This consolidation trend has called into question the long-term viability of community banks. A recent study concluded that prospects for community banks with assets between $\$ 100$ million and $\$ 1$ billion are generally favorable, but many community banks with assets under $\$ 100$ million are unlikely to be long-term survivors. That study also found that very few community banks were able to produce consistently high earnings in three geographical regions - viz., New England, rural areas of the Middle Atlantic, and the Pacific Southwest census region. ${ }^{11}$ It is probably not a coincidence that (i) Bank of America dominates banking markets in New England, and (ii) three major banks - Bank of America, U.S. Bank and Wells Fargo - jointly dominate banking markets in the Pacific Southwest (an area that includes Arizona, California, Colorado, Nevada, New Mexico and Utah).

A decline in the presence of community banks in a local or regional market is likely to diminish the availability of credit to SMEs in that market. A recent study found that SMEs were significantly less likely to obtain access to bank credit in urban or regional markets that were dominated by the largest banks. ${ }^{12}$ Accordingly, as discussed below in Section C, current statutory constraints on big bank mergers must be maintained and antitrust scrutiny of such mergers should be intensified. In addition, the state banking system must be maintained in order to support existing community banks and encourage the formation of new community banks.

In sum, the dual banking system should be preserved and strengthened in view of its outstanding record of fostering innovation and economic growth. To accomplish this goal, two steps must be taken. First, Congress must remove the competitive disparity that has been created by the sweeping preemption rules adopted by the OCC. Taking its cue from the OTS, the OCC adopted regulations in 2004 that effectively immunize national banks from state consumer protection laws that apply to other financial institutions. ${ }^{13}$ As a consequence of the OCC's rules, which Congress has never endorsed, national banks have secured a significant competitive advantage over state banks. For example, the OCC's rules encouraged several large, multistate banks to convert from state to national charters during 2004-05. Those conversions resulted in a

10 Wilmarth, "Transformation," supra note 4, at 252-53, 293-96; see also Gerald A. Hanweck \& Bernard Shull, "The bank merger movement: efficiency, stability and competitive policy concerns," 44 Antitrust Bulletin 251, 252-57 (1999).

11 R. Alton Gilbert, "The Viability of Small Banks in the United States," Networks Financial Policy Brief No. 2007-PB-07, April 2007 (available at http://ssrn.com/abstract $=985582$ ).

12 The same study also concluded that nonbank financial institutions did not provide enough credit to SMEs to make up for the reduced availability of bank credit in markets dominated by big banks. Steven G. Craig \& Pauline Hardee, "The impact of bank consolidation on small business credit availability," 31 Journal of Banking and Finance 1237 (2007).

13 See Wilmarth, "Dual Banking System," supra note 1, at 227-29, 233-37, 280-87, 321- 
significant shift in assets from the state banking system to the national banking system. The share of banking assets held by the state system, which had been stable since the mid-1970s, declined from $44 \%$ in 2003 to 33\% in 2005. Unless Congress reestablishes a basic parity between the competitive opportunities of national and state banks, it is doubtful whether the dual banking system can survive over the longer term. ${ }^{14}$

As described below in Part D, Congress can restore competitive parity by adopting uniform consumer protection legislation that applies equally to all financial service providers. The enactment of uniform consumer protection legislation would be similar to past legislation in which Congress has ensured that state banks enjoy parity with national banks in important areas such as intrastate and interstate branching, trust powers, usury, charter conversions, and financial subsidiaries. ${ }^{15}$

Second, federal supervision of state banks by at least one agency that is separate and independent of the OCC must be maintained. The supervisory responsibilities of the FRB and FDIC over state banks have encouraged those agencies to compete with the OCC in providing innovative and responsive regulation. Supervision of state-chartered banks by the FRB and the FDIC has thus reinforced the competitive dynamic created by the dual banking system. ${ }^{16}$ In view of the FRB's primary responsibility for regulating financial holding companies and controlling systemic risk - discussed below in Section E - Congress might decide that it is no longer desirable for the FRB to have direct supervisory authority over state banks. In that case, the separate category of state banks that are members of the Federal Reserve System could be eliminated, and the FDIC could be designated as the primary federal regulator for all FDICinsured state banks.

\section{Policy Recommentation No. 2: The dual banking system should be preserved and strengthened in order to promote innovation in banking regulation and to support the community bank sector as a crucial engine for economic growth.}

${ }^{14}$ Id. at 274-81, 286-87; Arthur E. Wilmarth, Jr., "OCC v. Spitzer: An Erroneous Application of Chevron That Should Be Reversed," 86 BNA's Banking Report 379 (Feb. 20, 2006) (hereinafter Wilmarth, "OCC v. Spitzer") (available at http://ssrn.com/abstract=886380), at 387; see also U.S. General Accountability Office, "OCC Preemption Rules: OCC Should Further Clarify the Applicability of State Consumer Protection Laws to National Banks," GAO06-387, April 2006, at 6, 28-29, 65-70.

15 Wilmarth, "Dual Banking System," supra note 1, at 254-57.

${ }^{16}$ Id. at 265; see also Richard J. Rosen, "Is Three a Crowd? Competition Among Regulators in Banking," 35 Journal of Money, Credit and Banking 969 (2003) (finding that the allocation of bank supervisory responsibilities among the FRB, FDIC and OCC improves the performance of banks by allowing them to change their business strategies more easily, because each bank can switch to a regulator that is more willing (and better suited) to approve and monitor the bank's chosen business strategy). 


\section{Policy Recommendation No. 3: At least one federal agency that is independent and separate from the OCC should be designated as the primary federal regulator for state- chartered banks.}

\section{Maintaining and Strengthening Limits on Bank Mega-Mergers}

As discussed above in Part B, the U.S. banking industry has experienced extensive consolidation over the past two decades. During 1990-2005, more than 5,400 bank mergers occurred, including 74 "mega-mergers" in which the buyer and seller each had more than $\$ 10$ billion of assets. As a result of these mergers, the percentage of banking assets and deposits held by the ten largest banks more than doubled, rising from $25 \%$ and $17 \%$, respectively, to $55 \%$ and $45 \%$, respectively. ${ }^{17}$

The consolidation trend presents four significant potential threats to the welfare of the banking industry and the broader economy. First, large bank mergers can produce excessive levels of market power, leading to diminished competition among banks. Studies have shown that banks in highly concentrated local banking markets are likely to charge higher interest rates and fees for lending and deposit services, and to pay lower interest rates on their deposits. ${ }^{18}$ Similarly, studies have found that large, multistate banks with significant market shares in regional banking markets typically charge higher prices for their financial services. ${ }^{19}$

Second, "mega-mergers" create "megabanks" that are "too big to fail" (TBTF) and, frequently, "too big to discipline adequately" (TBTDA) ${ }^{20}$ Megabanks enjoy major advantages by virtue of their TBTF and TBTDA status. Compared with smaller banks, megabanks are able to (i) pay significantly lower rates on their deposits, (ii) operate with significantly higher

17 Jones \& Oshinsky, supra note 9, at 1.

18 See Hanweck \& Shull, supra note 10, at 265-73 (citing studies); Wilmarth, "Transformartion," supra note 4, at 293-95 (same); Wilmarth, "Too Big to Fail," supra note 5, at 1020-23 (same).

19 See Hanweck \& Shull, supra note 10, at 273-79 (citing studies); Wilmarth, "Transformation," supra note 4, at 295-96 (same); Timothy H. Hannan, "Retail deposit fees and multimarket banking," 30 Journal of Banking \& Finance 2561 (2006); Timothy H. Hannan \& Robin A. Prager, "The competitive implications of multimarket bank branching," 28 Journal of Banking \& Finance 1889 (2004); Charles W. Calomiris \& Thanavut Pornrojnangkool, "Monopoly-Creating Bank Consolidation? The Merger of Fleet and BankBoston," National Bureau of Economic Research Working Paper 11351, May 2005 (available at http://www.nber.org/papers/w11351).

${ }^{20}$ Edward J. Kane, "Incentives for Banking Megamergers: What Motives Might Regulators Infer from Event-Study Evidence?", 32 Journal of Money, Credit, and Banking 671, 673-74, 689-95 (2000); Wilmarth, "Transformation," supra note 4, at 300-312. 
leverage (i.e., lower capital ratios), (iii) hold significantly lower loan-loss reserves in relation to their credit risks, and (iv) secure higher credit ratings and pay significantly lower interest rates on their bonds. ${ }^{21}$ The large subsidy enjoyed by TBTF institutions has been a major motivating factor behind the "mega-mergers" that have occurred in the U.S. banking industry during the past two decades. ${ }^{22}$ A recent study examined mergers in which the acquiring bank attained presumptive TBTF status by either (i) exceeding $\$ 100$ billion in total assets or $\$ 20$ billion in market value of equity, or (ii) becoming one of the eleven largest banks. The study found that, on average, the acquiring bank paid an excess premium of more than $\$ 1$ billion to the target bank in order to achieve presumptive TBTF status. ${ }^{23}$

Third, mega-banks present growing risks to the solvency of the FDIC's deposit insurance fund. A study by FDIC staff economists concluded that (i) consolidation in the banking industry has significantly increased the risk that the deposit insurance fund will become insolvent, and (ii) the failure of any of the ten largest banks would present a grave threat to the solvency of the fund. ${ }^{24}$

Fourth, due in large part to the existence of TBTF subsidies, consolidation has resulted in an intensification of risk within the financial services industry. During the banking crisis of the 1980s and early 1990s, large banks engaged in the most risky lending strategies. Eleven of the nation's fifty largest banks failed during 1980-92. Large banks failed at a higher rate than smaller banks during 1981-91, and large bank failures accounted for a majority of the losses suffered by the FDIC's bank insurance fund during 1986-94. ${ }^{25}$

21 See, e.g., Gary H. Stern \& Ron J. Feldman, Too Big to Fail: The Hazards of Bank Bailouts 30-40 (2004); William C. Handorf \& Lili Zhu, "US Bank Loan-Loss Provisions, Economic Conditions, and Regulatory Guidance," 16 Journal of Applied Finance 97, 110-12 (2006); Hanweck \& Shull, supra note 10, at 273-77; Maria F. Penas \& Haluk Unal, "Gains in bank mergers; Evidence from the bond markets," 74 Journal of Financial Economics 149 (2004); Arthur E. Wilmarth, Jr., "Wal-Mart and the Separation of Banking and Commerce," 39 Connecticut Law Review 1539 (2007) (hereinafter Wilmarth, "Banking and Commerce") (available at http://ssrn.com/abstract=984103), at 1590-92 (including studies cited therein).

${ }^{22}$ See Stern \& Feldman, supra note 21, at 32-33, 60-79; Hanweck \& Shull, supra note 10 , at 273-77; Kane, supra note 20 , at 673-74, 690-95.

${ }^{23}$ Elijah Brewer III \& Julapa A. Jagtiani, "How Much Would Banks Be Willing to Pay to Become "Too-Big-to-Fail and to Capture Other Benefits?", July 2007 (available at http://ssrn.com/abstract=1003163), at 17-26.

${ }^{24}$ Jones \& Oshinsky, supra note 9.

${ }^{25}$ See Wilmarth, "Transformation," supra note 4, at 312-16, 444-45, and sources cited therein. 
Currently, as discussed below in Part E, the U.S. financial services industry confronts its most serious crisis since the early 1990s. Once again, the greatest risks are concentrated in the largest depository institutions. Citigroup, Bank of America, Wachovia, Washington Mutual and Countrywide have all reported serious losses, as have three large foreign banks with extensive U.S. operations (HSBC, UBS and Barclays) and two large securities firms that control FDICinsured thrifts and industrial banks (Merrill Lynch and Morgan Stanley). The current crisis should establish beyond any doubt that TBTF subsidies encourage the largest financial institutions to pursue excessively risky business strategies. ${ }^{26}$

For all of the above reasons, Congress should maintain existing statutory limits on bank mega-mergers, including those which (i) prohibit any interstate bank merger or any interstate acquisition of a bank by a bank holding company that would give the acquiring institution control of more than $10 \%$ of the total amount of deposits held by all insured depository institutions in the United States (the "10\% nationwide deposit cap"), and (ii) prohibit any such merger or acquisition if it would give the acquiring institution control of more than $30 \%$ of the total amount of deposits held by all insured depository institutions in a single state, unless that percentage is increased by that state's law (the "30\% statewide deposit cap"). See 12 U.S.C. $1831 \mathrm{u}(\mathrm{b})(2) \& 1842(\mathrm{~d})(2)$. In addition, Congress should require intensified scrutiny and special conditions for any bank merger or acquisition in which the acquiring institution would gain control of more than $2 \%$ of nationwide deposits or more than $20 \%$ of statewide deposits in any state. For example, heightened requirements for such mergers could include (i) a more intensive analysis of all relevant competitive factors, (ii) increased attention to the question of whether the merger under review would produce net benefits to consumers and other members of the public, including benefits that would accrue to each of the urban and regional markets affected by the merger, and (iii) a requirement that megabanks - i.e., those controlling more than $2 \%$ of nationwide deposits - must maintain higher capital ratios and pay higher deposit insurance premiums to the FDIC. ${ }^{27}$

Policy Recommendation No. 4: Maintain the existing statutory limits on bank mergers and acquisitions, including the $10 \%$ nationwide deposit cap and the $30 \%$ statewide deposit cap.

\section{Policy Recommendation No. 5: Require intensified scrutiny and special conditions for any merger or acquisition in which the acquiring institution would gain control of more than $2 \%$ of nationwide deposits or more than $20 \%$ of statewide deposits in any state.}

${ }^{26}$ My previous articles have emphasized the connection between TBTF/TBTDA status and excessive risk-taking, as well as the inadequacy of current regulatory approaches to control such risk-taking by megabanks and other large financial conglomerates. See Wilmarth, "Transformation," supra note 4, at 444-76; Wilmarth, "Banking and Commerce," supra note 21, at $1588-93,1616-21$.

27 See Bernard Shull \& Gerald A. Hanweck, "Bank Merger Policy: Proposals for Change," 114 Banking Law Journal 214, 225-31 (2002). 


\section{Providing More Effective Protection to Consumers of Financial Services}

As discussed in Part B, the OCC and OTS have adopted regulations that preempt the application of state consumer protection laws to national banks and federally-chartered thrifts or their operating subsidiaries. In particular, the OCC and OTS rules targeted state laws that attempted to protect consumers against predatory or deceptive lending practices with respect to home mortgages and credit cards. ${ }^{28}$ The OCC also adopted a regulation designed to preempt the states' authority to enforce applicable state laws against national banks. ${ }^{29}$

The OCC and OTS rules effectively prevented the states from enforcing their predatory lending laws against federally-chartered depository institutions or their operating subsidiaries. The OCC's rules also provided national banks with a significant competitive advantage over state banks, as shown in Part C. In addition, the OCC's rules have allowed national banks to impose record levels of penalty interest rates, late payment fees, over-the-limit charges, and other charges and fees on credit card holders.

In contrast to their aggressive preemption efforts, the OCC and OTS failed to provide any meaningful protection for consumers that would replace the state laws they preempted. Until recently, the OCC's rules contained only one mandatory regulation with regard to predatory lending. That regulation provided in general terms that national banks could not make real estate loans based "predominantly" on the value of the borrower's collateral and without considering the borrower's ability to repay the loan. ${ }^{30}$ However, until June 2007, the OCC and OTS allowed their regulated institutions to make subprime 2/28 and 3/27 loans based solely on the borrower's ability to pay the introductory "teaser" rate and without taking account of the borrower's ability to pay the fully amortized rate. In addition, the OCC and OTS did not prohibit their regulated institutions from imposing heavy prepayment penalties that made it extremely costly for subprime borrowers to refinance $2 / 28$ or 3/27 loans. These types of abusive subprime loans have experienced the worst delinquency and default rates during the past year. In addition, the origination, funding and securitization of such loans have inflicted severe losses on several major national banks (including Citigroup, Wachovia, HSBC and UBS), as well as Countrywide (which held a national bank charter until the end of 2006, and a federal thrift charter since that time), and two major federally-charterd thrifts (Washington Mutual and IndyMac). To date, no large state-chartered bank has reported comparable losses.

Congress should adopt comprehensive legislation that establishes uniform consumer protection standards for all home mortgage lenders, credit card lenders, and other providers of consumer credit. Such legislation should remove the competitive disparity created by the OCC's

${ }^{28}$ See Wilmarth, “Dual Banking System,” supra note 1, at 227-29, 233-37, 274-93, 306, 324-27, 347 n.506.

${ }^{29}$ See $i d$. at 228-29; Wilmarth, "OCC v. Spitzer,” supra note 14.

30 See Wilmarth, "Dual Banking System," supra note 1, at 306-08. 
preemption rules by ensuring that national banks and state banks must observe the same federal standards of consumer protection. The House recently passed legislation on mortgage lending (H.R. 3915) that would represent an important first step toward achieving this goal.

For two reasons, such legislation should prohibit the OCC from issuing regulations that preempt state laws except in specific areas where Congress has given the OCC explicit authority to adopt preemptive rules. ${ }^{31}$ First, the OCC's 2004 preemption rules were adopted without express congressional authorization and undermined the dual banking system by conferring an unwarranted competitive advantage on national banks. Second, the OCC's regulatory approach has proven to be deeply flawed. The OCC (like the OTS) failed to protect its regulated institutions, their customers and the financial system from severe and potentially crippling losses resulting from unsound lending and securitization activities.

In addition, the legislation should establish a separate and independent federal authority that would be responsible for enforcing federal consumer protection laws against all financial service providers, including national banks and their operating subsidiaries. This new federal authority (which I will call the "Financial Services Consumer Protection Authority" or "FSCPA") could be a separate bureau of the Federal Trade Commission (FTC) or a new independent agency. The FSCPA should be funded by congressional appropriations - not by assessments on financial institutions - in order to assure the FSCPA's independence from the financial services industry. The OCC has failed to provide effective enforcement of consumer protection laws, particularly with regard to the largest national banks. The OCC's financial incentives provide the most plausible explanation for its poor enforcement record. The OCC is understandably reluctant to take vigorous enforcement measures against its biggest regulated constituents, because those banks fund most of the OCC's budget. ${ }^{32}$ If the FSCPA is funded by taxpayer revenues, it should feel a greater responsibility to protect the public from unlawful or abusive financial practices.

Finally, Congress should recognize the authority of state attorneys general to enforce applicable state consumer protection laws - including laws prohibiting unfair and deceptive practices (UDAP laws) - against all financial service providers, including national banks and their operating subsidiaries. The operations of state attorneys general are funded by taxes paid by citizens, and they are politically accountable to those citizens. It is therefore not surprising that state attorneys general have played an essential role in protecting consumers from unlawful practices committed by both state-chartered and federally-chartered financial institutions. ${ }^{33}$ In

31 If my Policy Recommendation No. 1 is adopted, the thrift charter and the OTS would disappear and it would not be necessary for Congress to overrule the OTS' preemptive regulations.

32 See Wilmarth, "Dual Banking System," supra note 1, at 274-79, 296-97, 353-56; Wilmarth, "OCC v. Spitzer," supra note 14, at 387.

33 Wilmarth, "Dual Banking System," supra note 1, at 316, 348-52. 
order to ensure coordination between the FSCPA and state attorneys general, Congress could require a state attorney to give prior notice to the FSCPA, and to allow the FSPCA to take appropriate action, before the state attorney general could initiate a formal proceeding against a national bank to enforce a state consumer protection law.

Policy Recommendation No. 6: Congress should adopt comprehensive legislation that establishes uniform consumer protection standards for all home mortgage lenders, credit card lenders, and other providers of consumer credit.

Policy Recommendation No. 7: Congress should prohibit the OCC from issuing regulations that preempt state law except in specific areas where Congress has given the OCC explicit authority to adopt preemptive rules.

Policy Recommendation No. 8: Congress should establish a separate and independent authority to enforce federal consumer protection laws against all financial service providers, including national banks. This new authority should be funded by congressional appropriations in order to ensure its independence from the financial services industry.

Policy Recommendation No. 9: Congress should authorize state attorneys general to enforce applicable state consumer protection laws against all financial service providers, including national banks.

\section{E. Controlling Systemic Risk}

\section{The Current Financial Crisis}

In recent weeks, leading commercial banks and Wall Street firms have reported more than $\$ 40$ billion of losses resulting from originating, funding and securitizing subprime and nonprime mortgage loans, and from issuing credit enhancements and derivatives related to those loans. The CEOs of Citigroup and Merrill Lynch have been forced to resign. Some analysts have predicted that major banks and Wall Street firms will ultimately incur losses of more than $\$ 200$ billion from the subprime lending debacle.

Many analysts and bank executives have admitted that they cannot reliably estimate the full extent of losses that financial institutions may ultimately suffer from the subprime disaster. The opaque instruments and complex off-balance-sheet structures created by large financial conglomerates make it impossible to measure the risks these institutions have assumed.

Meanwhile, our nation is experiencing a wave of defaults and delinquencies on residential mortgage loans. Our housing industry has been shattered, and many communities have been devastated by declining home values and widespread foreclosures. Not surprisingly, the public has lost confidence in the integrity of our financial institutions and markets.

In defending their past oversight of subprime lending and securitization activities, federal 
regulators have claimed that "market discipline" can be relied upon to restrain the behavior of financial institutions. However, market discipline is clearly ineffective with respect to the TBTF conglomerates that now dominate our financial system. During the current crisis, regulators have felt compelled to support major financial institutions whenever they were threatened by adverse market conditions. When the financial markets cut off financing for Countrywide and other major financial institutions last summer, the FRB and the Federal Home Loan Bank (FHLB) System provided massive liquidity assistance. The Fed also allowed six leading banks (Citigroup, Bank of America, JP Morgan Chase, Deutsche Bank, Barclays and Royal Bank of Scotland) to extend credit to their securities affiliates for a "temporary" period without regard to the restrictions on affiliate transactions imposed by Section 23A of the Federal Reserve Act. Similarly, the Treasury Department has publicly and actively supported the creation of an industry-funded "master liquidity enhancement conduit" designed to relieve the pressure on Citigroup and other big banks that are plagued by large exposures to asset-backed commercial paper held by "structured investment vehicles" (SIVs).

In contrast to the support provided to TBTF conglomerates, federal regulators took no action to prevent the failure of dozens of smaller nondepository institutions as well as two small banks (Netbank and Miami Valley Bank). Thus, the current crisis reveals in vivid terms the reality and magnitude of TBTF subsidies for major financial conglomerates. ${ }^{34}$

There are many questions that must be answered in resolving the current crisis in our financial services industry. For example, why were federal regulators apparently so reluctant to question the assumptions underlying (i) the "internal risk models" that big commercial and investment banks followed in their subprime lending and securitization programs, and (ii) the external credit ratings that those institutions obtained from credit ratings agencies? Why did regulators wait until June 2007 to instruct banks that they must underwrite 2/28 and 3/27 loans at the fully amortized rate rather than the teaser rate? Why weren't regulators concerned about the adverse impact of prepayment penalties and other fees imposed on subprime borrowers? Why didn't regulators recognize the credit and reputational risks that major banks and thrifts (including those controlled by securities firms) were assuming under their subprime lending and securitization programs? Why didn't regulators know about the liquidity puts and other credit enhancements that major banks reportedly provided to off-balance-sheet SIVs and other purchasers of asset-backed securities? Why didn't regulators question the reasonableness and objectivity of credit ratings that routinely assigned "AAA" ratings to $80 \%$ of the tranches in securities backed entirely by high-risk subprime mortgages - especially when the ratings agencies negotiated their ratings and were paid large fees by the banks that issued those securities?

34 See Wilmarth, Banking and Commerce, supra note 21, at 1589-90 (stating that "[d]uring a systemic crisis, the safety net subsidy is likely to become very large because the federal government, in effect, provides 'catastrophe insurance.' . . . The existence of a subsidy for TBTF institutions is further indicated by the fact that no major U.S. bank has ever surrendered its bank charter and chosen to operate as a nonbank"). 
The current crisis raises additional troubling questions in light of recent experience with financial abuses and excesses. Many of the big banks and Wall Street firms that played key roles in the subprime lending and securitization debacle also were underwriters for the securities that produced a similar boom-and-bust cycle in the dotcom and telecom industries in the late 1990s. Many of the same institutions were also tarnished by scandals involving Enron, WorldCom, biased investment analysts, manipulative practices in initial public offerings, and trading abuses in mutual funds. Why weren't these institutions subject to increased regulatory scrutiny in light of their recent mistakes and misconduct?

The bursting of the dotcom and telecom bubble destroyed $\$ 8$ trillion of investment value during 2000-02. The housing bust is expected to destroy at least $\$ 2$ trillion of market value in our housing stock, in addition to the losses it will inflict on financial institutions. Two devastating bubbles and busts in less than a decade demonstrates that our financial regulatory system is deeply flawed. "Market discipline" can no longer be relied upon as the primary arbiter of financial industry practices.

\section{Needed Reforms to Control Systemic Risk}

The policy recommendations listed in Part D address some of the regulatory flaws revealed by the subprime crisis. Many of the questions listed in Part E(1) highlight the need for a new regulatory approach that emphasizes vigorous financial supervision and effective protection of consumers. In my remaining comments, I wish to focus on structural reforms that are needed to improve our ability to control systemic risk.

Congress should designate the FRB as the agency having primary authority for controlling systemic risk in the financial markets. To accomplish this goal, all "significant" financial institution holding companies - i.e., those with more than a specified amount of consolidated assets (e.g., $\$ 200$ billion, as adjusted for inflation) - should be required to register with the FRB as financial holding companies under 12 U.S.C. 1843(k) if they control an FDICinsured bank. Thus, all bank holding companies, securities firms and insurance companies would be required to register as financial holding companies, and would become subject to the FRB's oversight, if they meet the consolidated asset test for "significance." 35

The Gramm-Leach-Bliley Act (GLBA) established the FRB as the "umbrella regulator" for financial holding companies with the clear intention that the FRB has primary responsibility for ensuring the overall safety and soundness of financial holding companies and controlling systemic risk. Unfortunately, GLBA's design was not completely implemented, because it did not require all large financial conglomerates that control FDIC-insured depository institutions to become financial holding companies. Thrift holding companies and holding companies that

35 For a similar proposal, see Henry Kaufman, "Who’s Watching the Big Banks?," Wall Street Journal, Nov. 13, 2007, at A25 (advocating the creation of a "Federal Financial Oversight Authority," which would "function under the auspices of the Federal Reserve" and would supervise the 10-20 largest financial conglomerates). 
control industrial loan companies (ILCs) were exempted from the FRB's oversight.

The severe problems encountered by Countrywide, Washington Mutual, IndyMac, Merrill Lynch and Morgan Stanley demonstrate that neither the OTS nor the SEC can adequately perform the role of systemic risk regulator for large financial conglomerates that control FDICinsured depository institutions. Countrywide has shown that a financial conglomerate facing a liquidity crisis in the financial markets can rapidly shift its operations to its depository institution subsidiary, which can then raise funds by soliciting FDIC-insured deposits and seeking advances from the FRB and/or the FHLB System. Thus, a financial conglomerate can quickly expand its FDIC-insured subsidiary for the specific purpose of maximizing the federal safety net subsidies available to that institution.

My Policy Recommendation No. 1 would require all thrift institutions to convert to bank charters and would eliminate the OTS, thereby ending the OTS' role as a holding company supervisor. The SEC is not designed or equipped to serve as a systemic risk supervisor for large financial conglomerates. FDIC-insured ILCs have powers equivalent to commercial banks, except for the ability to accept demand deposits from for-profit businesses. Accordingly, Congress should remove the exemption for ILCs from the Bank Holding Company Act, at least with respect to any corporate owner of an ILC that would satisfy the "significance" test described above (e.g., Merrill Lynch and Morgan Stanley). ${ }^{36}$

The FRB is the only agency with the necessary expertise and powers to act as "systemic risk regulator." The FRB is the lender of last resort (LOLR) and must therefore play a key role in preventing the collapse of a major financial institution that could trigger systemic risk within the financial markets and the broader economy. The recent Northern Rock episode in the United Kingdom demonstrates the mistake of separating the LOLR function from concurrent responsibility for regulating financial institutions to prevent systemic risk. The U.K. Financial Services Authority (FSA) had authority to regulate Northern Rock but could not act as LOLR. The Bank of England had authority to act as LOLR but could not regulate Northern Rock. There was an apparent breakdown in communications between the FSA and the Bank of England due to this division of responsibilities. As a result, the Bank of England reportedly did not appreciate the need for liquidity assistance and the potential systemic impact of a failure at Northern Rock until depositors began to run on the institution. The U.K. Treasury felt compelled to announce a blanket guarantee of all deposits in order to stop the run, and the Bank of England provided

36 In Wilmarth, "Banking and Commerce," supra note 14, I have argued that Congress should prohibit any further acquisitions of FDIC-insured ILCs by commercial firms. With the exception of 15 ILCs that are currently owned by commercial firms, all corporate owners of FDIC-insured industrial banks are financial firms that could satisfy the criteria for financial holding companies under 12 U.S.C. 1843(k). If it wished, Congress could "grandfather" the commercial owners of those 15 ILCs and could exempt them from FRB oversight, with appropriate safeguards to ensure that the commercial owners could not become a source of systemic risk within the financial markets. 
advances to Northern Rock that currently exceed $\$ 50$ billion. ${ }^{37}$

Congress could designate the FRB as the systemic risk regulator for all "significant" financial conglomerates without disturbing GLBA's existing scheme of functional regulation. Federal bank regulators, the SEC and state insurance regulators could continue to carry out their existing roles as functional supervisors within GLBA's framework. However, Congress should give the FRB sufficient authority so that it can (i) monitor the aggregate risks created by "significant" financial holding companies and (ii) take all necessary steps to prevent those companies from engaging in practices that have the potential to create systemic risk.

As a further step toward controlling systemic risk, Congress should reduce the scope of protection provided by the FDIC's deposit insurance fund (DIF). Congress should mandate that the DIF can only be used to protect holders of insured deposits. The DIF should be prohibited from making any payments to uninsured depositors or other uninsured bank creditors. Congress should repeal the "systemic risk" exception in the Federal Deposit Insurance Act, 12 U.S.C. 1823(c)(4)(G), which allows the FDIC to protect uninsured depositors and other creditors in TBTF banks. All responsibility for protecting creditors of TBTF institutions should be assigned to the FRB under its authority as LOLR and systemic risk regulator. In addition, Congress should require the FRB to impose assessments on "significant" financial holding companies in order to recover the FRB's cost of providing financial assistance to any such company. These reforms would (i) focus the FDIC on its primary mission of protecting insured depositors, (ii) remove the DIF and smaller banks as potential funding sources for rescues of TBTF banks, (iii) require TBTF financial conglomerates to internalize the cost of safety net subsidies provided to similar organizations, and (iv) encourage TBTF conglomerates to monitor more closely the risks assumed by their peers, in view of their contingent liability for TBTF rescues.

Policy Recommendation No. 10: Congress should designate the FRB as the systemic risk regulator for each "significant" financial conglomerate that controls an FDIC-insured bank. Each such conglomerate should be required to register as a financial holding company and to become subject to the FRB's oversight.

Policy Recommendation No. 11: Congress should prohibit the FDIC's deposit insurance fund from making any payments to uninsured depositors or other uninsured bank creditors. Congress should repeal the "systemic risk" exemption in the Federal Deposit Insurance Act.

Policy Recommendation No. 12: All responsibility for protecting creditors of "too big to fail" financial institutions should be assigned to the FRB under its authority as lender of last resort and systemic risk regulator. Congress should require the FRB to impose assessments on "significant" financial holding companies in order to recover the

37 See, e.g., "Briefing: Northern Rock: Lessons of the fall," Economist, Oct. 20, 2007, at 91; Kate Burgess et al., "Week that shook the banking world," Financial Times, Sept. 22, 2007, at 3. 
FRB's cost of providing financial assistance to any such company.

$* * * * * * * * * * * * * * * * * * * * * * * * * * * * * * * * * * * * * * * * * * * * * * * * *$

Thank you for your kind consideration of the foregoing comments.

Very truly yours,

Arthur E. Wilmarth, Jr.

Professor of Law

The George Washington University Law School 